\title{
Antioxidant dietary fiber-based bakery products: a new alternative for using plant-by-products
}

\author{
Rodrigo SUBIRIA-CUETO ${ }^{1}$, Alma Janet CORIA-OLIVEROS ${ }^{1}$, Abraham WALL-MEDRANO ${ }^{1}$, \\ Joaquín RODRIGO-GARCÍA ${ }^{1}$, Gustavo Adolfo GONZÁLEZ-AGUILAR², Nina del Rocio MARTINEZ-RUIZ ${ }^{1 *}$, \\ Emilio ALVAREZ-PARRILLA ${ }^{1 *}$
}

\begin{abstract}
Agro-industrial processing activities generate by-products that are discarded at high economic and environmental costs; however, many of them still contain high levels of bioactive compounds (BCs) such as dietary fiber (DF) and phenolic compounds (PCs), which, when combined, are known as antioxidant dietary fiber (ADF). These BCs have properties that are beneficial to our health, among them anti-inflammatory, antioxidant and cardioprotective. Moreover, DF can regulate glucose and cholesterol levels. The mechanism of ADF action depends on its chemical structure and the interactions between the DF and PCs in it. Recent studies have reported the incorporation of several of these by-products on a diet through food products consumed worldwide, such as bread. This review describes the chemical characteristics of the ADF complex and the effect of its molecular interactions on sensory, nutritional and health-promoting properties of functional bakery goods.
\end{abstract}

Keywords: by-product; phenolic compounds; dietary fiber; interactions; antioxidant dietary fiber; health benefits.

Practical Application: Use of agro-industrial by-products on the formulation of functional bakery products.

\section{Introduction}

In recent years, new trends in the food market are in constant motion as consumers change their demands when purchasing healthier food. This interest in acquiring healthier foods has focused on the use of functional ingredients (FIs) that are safe while offering therapeutic and potential nutritional effects (Dziki et al., 2014). Whereas some conventional ingredients in different food products offer low nutritional content and poor health benefits, FIs have a high content of BCs, among then DF and PC. FIs are already used in different products designed to satisfy specific consumer needs (Flecha, 2015). Helping in the treatment of a disease or acting as prevention to one is one of such needs (Tebben et al., 2018). Epidemiological studies strongly indicate that diet plays a fundamental role in the prevention and treatment of chronic diseases. The consumption of foods rich in BCs, especially antioxidants, reduces the presence of illness linked to oxidative stress (Dziki et al., 2014).

Functional foods have been defined as foods that contain a component, nutrient or non-nutrient, with selective activity related to one or several functions of the organism, with an added physiological effect above its nutritional value and whose positive actions justify the claim of their functional (physiological) or even healthy character by reducing the risk factor (Silveira Rodríguez et al., 2003). These beneficial properties are provided by molecules such as BCs found in biological matrices, mainly fruits, vegetables, cereals, dairy products, and meats. For the development of functional foods, the selected ingredients play a crucial role part in achieving specific beneficial effects without modifying the sensory properties of the final product (Rincón-León, 2003).

The evolution of functional ingredients has been constant. Initially, only vitamins (vitamin C, E and folic acid) and minerals (zinc, calcium, iron) were used as fortifiers. More specific micronutrients such as omega-3 fatty acids, phytosterols, and insoluble fibers were added later. Dziki et al. (2014), which illustrates that research and incorporation of BCs have been relevant in the improvement of consumer health. Today, researchers are actively studying the impact of a wide variety of dietary options rich in fiber -both soluble and insoluble-, essential amino acids, and PCs. For the further development of new functional foods, studies should guarantee the sensory and nutritional characteristics of the new products (MartinezSaez et al., 2017). According to some European establishments, functional foods have been launched as part of dairy products, confectionery, beverages, baked goods, and baby food (Day et al., 2009; Siró et al., 2008).

An interesting approach to increase the consumption of BCs is developing new functional foods using highly consumed products. Among the most consumed foods are juices and bakery products, which present high carbohydrate content, sometimes accompanied by high-fat content in their formulation. Regardless, their easy malleability renders them ideal for enrichment and further application as carriers of functional ingredients (Burton \& Lightowler, 2006; Siró et al., 
2008). Some functional bakery goods have been developed using different sources of plant by-products. These by-product enriched goods (bread, biscuits, cookies) out because of their high contents of DF, antioxidants, and carotenoids. However, it is necessary to evaluate the possible interactions among these added compounds and their implications on the sensory and nutritional properties of the new products.

Plant by-products are a complex matrix that possesses many different molecules that can interact among them. These molecules have been reported to present some specific biological activities after consumption in addition to providing chemical, physical, and biological characteristics to plants (Segneanu et al., 2017). The effects that have been mostly studied are those that show therapeutic pharmacological effects, such as antiviral, antispasmodic, cardioprotective, anti-inflammatory or anticancer (Drago Serrano et al., 2006; Segneanu et al., 2017). However, it must be highlighted that the beneficial health effects are linked to the type of $\mathrm{BC}$ and its interactions with the food matrix (Drago Serrano et al., 2006; Sagar et al., 2018).

Until recently, by-products were considered waste products from the fruit, vegetable, grain, beer, wine, marine, dairy and meat industries. By-products represent approximately $38 \%$ of the total food production, which results in great environmental inconvenience because of their high content of organic matter, high levels of water activity, and the microbiological hazard they represent (Helkar et al., 2016). According to the Food and Agricultural Organization of the United Nations (FAO), over 1.3 billion tons of food is wasted each year. Fruits and vegetables are among the largest food waste contributors, with approximately $44 \%$ of the total waste (Tassoni et al., 2020). Since agro-industrial by-products contain high quantities of BCs that can be used to formulate new foods with high levels of BCs, recent studies have been focusing on the use of these by-products in the formulation of functional foods (Garcia et al., 2016; Lafarga et al., 2013), with DF and PCs among the primary $\mathrm{BCs}$ found in agro-industrial by-products.

\section{Dietary fiber}

Dietary fiber (DF) is a complex group of BCs present in a wide range of fruits and vegetables that, when consumed in the diet, may prevent some conditions such as diabetes, hypertension, and coronary disease (Saura-Calixto, 1998). For this reason, DF has become a prospective option for the development of innovative foods, supplements or functional ingredients (Dhingra et al., 2012).

DF is a component of plant cell walls, responsible for providing structural support to fruits and vegetables. Chemically, DF is constituted of several carbohydrate polymers such as homopolysaccharides, heteropolysaccharides, lignins, oligosaccharides, resistant starches, gums, and mucilages (Ahmad \& Khalid, 2018).

DF is defined as non-starchy polysaccharides resistant to acidalkaline conditions in the digestive system. Some of these complex carbohydrates can be totally or partially fermented in the colon by intestinal microbiota. DF is classified according to its solubility in soluble and insoluble dietary fiber (Figure 1) (Caprita et al., 2010; Kay, 1982). Insoluble dietary fiber (IDF) presents $\beta-1-4$ glucosidic bonds, which provides it with resistance to degradation in highly acid or alkaline environments (Dhingra et al., 2012). Cellulose is one of the most common examples of this type of fiber. This molecule is the most abundant fiber in nature, and it is made of up to 10,000 units of glucose linked by $\beta-1-4$ bonds (Caprita et al., 2010; Dhingra et al., 2012).

Another type of IDF is hemicellulose, linear or branched molecules constituted by glucose molecules with $\beta-1-4$ bonds. Unlike cellulose, hemicellulose contains other monomeric units in its structure, such as xylose, galactose, mannose or arabinose (Caprita et al., 2010; Dhingra et al., 2012). Hemicellulose is also part of the plant cell wall and can be subclassified as acidic or neutral depending on the content of glucuronic and galacturonic acids (Kay, 1982). Both cellulose and insoluble hemicellulose promote intestinal transit, increase faecal volume, act as prebiotic in the microflora, and reduce cholesterol (Mudgil \& Barak, 2013).

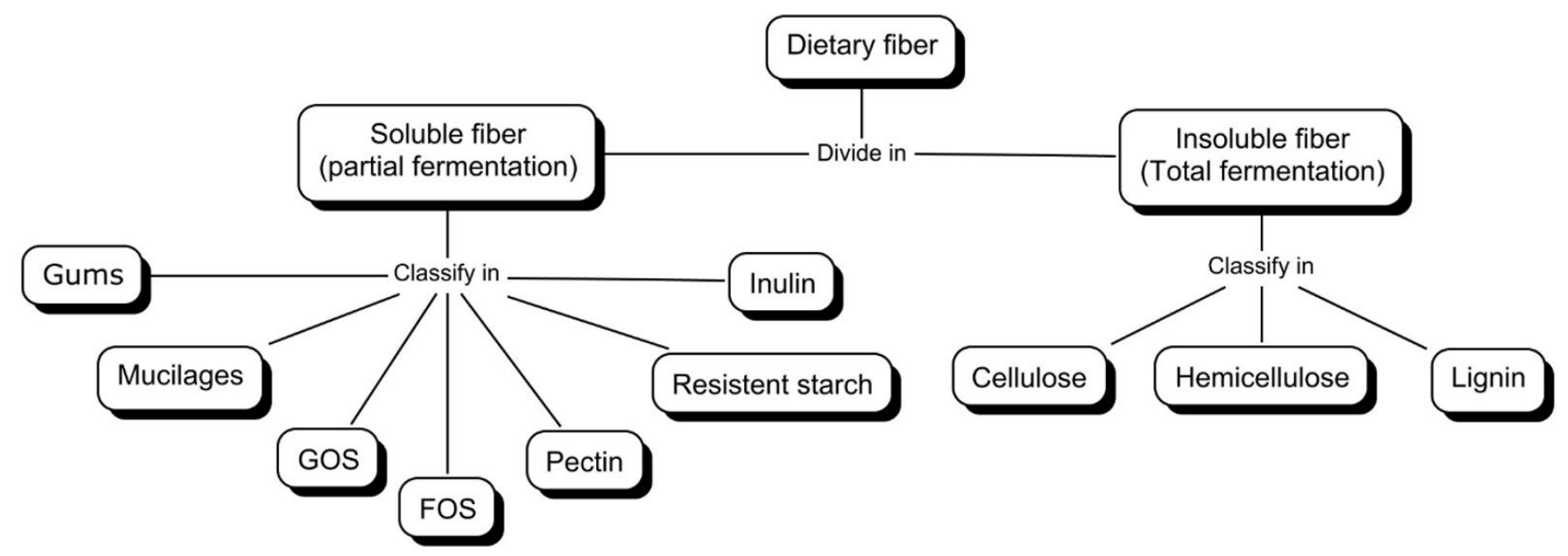

Figure 1. Dietary fiber (DF) classification. 
Lignin is not considered a polysaccharide but rather a complex polymer. It contains oxygenated phenylpropane, including sinapyl, comniferyl and p-coumaryl alcohols (Dhingra et al., 2012). One of the main differences in lignins is the number of methoxyl groups and their molecular weight. These polymers are bonded to cellulose and contribute to stiffening the plant cell wall, making it resistant to physical damage. Lignin is found in algae, vascular plants, insects and woody foods like celery and nuts. When consumed, lignin can beneficially affect gastrointestinal physiology in humans thanks to its sturdiness, which renders it resistant to digestion (Escudero Álvarez \& Gonzalez Sánchez, 2006; Mudgil \& Barak, 2013). Other nonstarch glucose polymers include waxes or cutin, which contain long chains of hydroxyaliphatic fatty acids (Caprita et al., 2010; Kay, 1982).

Soluble dietary fiber (SDF) are water-soluble polysaccharides that can hold between 15 and 20 times its weight in water (Dhingra et al., 2012). SDF stimulates gastric secretion, accelerates intestinal movement, shortens the intestinal transit time, and reduces the absorption of cholesterol, glucose, and fat. SDF his fermented in the colon producing $\mathrm{CO}_{2}, \mathrm{H}_{2}, \mathrm{CH}_{4}$ and short-chain volatile fatty acids such as propionic and butanoic acid among others (Badui Dergal, 2012).

One of the most common SDF is pectin, composed of d-galacturonic acids linked to rhamnose units, branched with hexose and pentose chains (Mudgil \& Barak, 2013). Arabinose and galactose are attached in as side chains (Caprita et al., 2010). Pectin provides an intercellular base and support to the plant cell wall (Dhingra et al., 2012). Pectin is highly soluble in water and can form gels (Caprita et al., 2010; Mudgil \& Barak, 2013). This ability to allows pectin to entrap cholesterol, thus reducing its levels in the body (Mudgil \& Barak, 2013).

Gums and mucilage are other types of SDF found in the outer layers of seeds, roots and vegetable leaves (Herrera, 2013; Mudgil \& Barak, 2013). Their chemical composition contains hydrophilic compounds and acetylated or methylated uronic acids (Herrera, 2013; Mudgil \& Barak, 2013). Due to their affinity to water and organic material, they can form gels, which in turn renders them ideal as thickeners, gelling and emulsifying agents in pharmaceutical and food products (Dhingra et al., 2012; Herrera, 2013; Mudgil \& Barak, 2013). Glucans are SDFs found in the cell wall that may regulate glucose, insulin and cholesterol levels in the human body (Mudgil \& Barak, 2013).

\section{Phenolic compounds}

Phenolic compounds (PCs) are secondary metabolites that have been extensively researched for their physiological actions in the human body. These compounds are of plant origin and are responsible for pigmentation, UV protection, internal signaling and protection against pathogens (Murkovic, 2015; Tomás-Barberán \& Clifford, 2000). Also, PCs confer organoleptic characteristics such as colour, flavour and aroma to multiple plants and contribute to the functional properties of fruits and vegetables (Garrido \& Borges, 2013; Sagar et al., 2018).

PCs present one or more phenolic groups in their complex structure, and so far, more than 8000 PC compounds have been described. PCs are classified mainly into flavonoids and nonflavonoids, depending on the number of phenolic rings and structure complexity (Figure 2) (Halake et al., 2016).

\subsection{Flavonoids}

Flavonoids, one of the main PC groups, display a structure with at least fifteen carbon atoms distributed between two aromatic rings ( $\mathrm{A}$ and $\mathrm{B}$ ) linked by three carbon atoms that form an oxygenated heterocycle (ring $\mathrm{C}$ ). Flavonoids can be found as aglycones, glucosides and methylated derivatives. Flavonoids can be further divided into six families, depending on their structural differences: flavones, flavonols, flavan-3-ol, isoflavones, flavanones and anthocyanins (Halake et al., 2016). These families will be briefly described next.

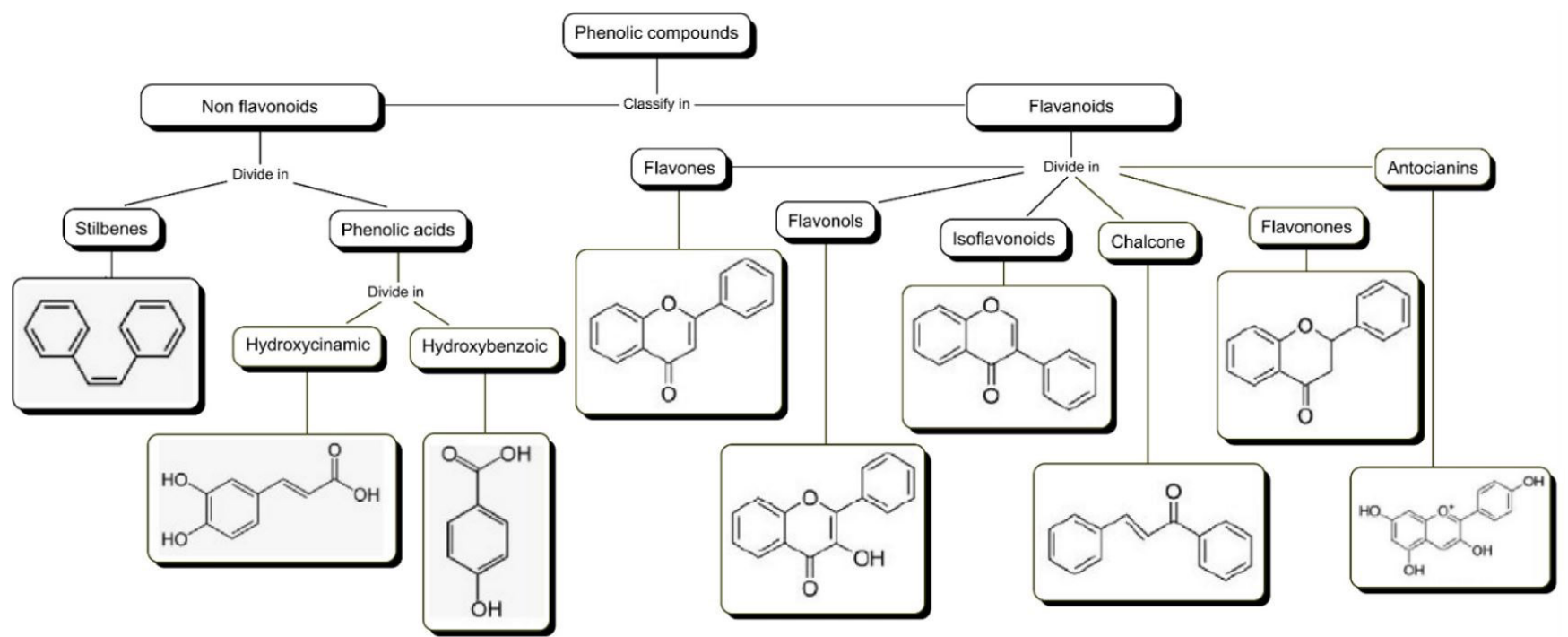

Figure 2. Phenolic compounds (PC) classification. 
Flavones, a prominent member of the flavonoid group, present a keto group in $\mathrm{C} 4$ and a double bond between $\mathrm{C} 2-\mathrm{C} 3$ of ring $\mathrm{C}$, and varying numbers of hydroxyl groups. They exist in a wide variety of edible plants such as celery, parsley, red pepper, chamomiles, mint, and ginkgo biloba the form of aglycones or glycosylic derivatives (Panche et al., 2016). Apigenin and luteolin are examples of this group, which only differ in their C5 substituents (Garrido \& Borges, 2013).

Flavonols are structurally like flavones, with the difference that they present a hydroxyl group at C3 of ring C. Quercetin and its glycosylated and methylated derivatives are the most prominent examples of this group.

The group Flavan-3-ol present a more flexible structure because they lack the keto group at $\mathrm{C} 4$ and the double bond between $\mathrm{C} 2-\mathrm{C} 3$ of ring $\mathrm{C}$. They are widely found as aglycone in the plant kingdom including some fungi and algae. Catechin and epicatechin are the main compounds of the flavan-3-ols. They can form polymeric structures known as proanthocyanidins or condensed tannins.

Isoflavones are structured like flavones with the difference that ring B is attached to C3, instead of C2. They are present mainly in soy products and in some legumes. They exist both as aglycones and glycosylic derivatives. (Halake et al., 2016).

The group of Flavanones display in their structure the keto group at $\mathrm{C} 4$, but lack the double bond between $\mathrm{C} 3-\mathrm{C} 4$, and have a chiral centre in C2. Naringenin and hesperitin are the main representants of this group of flavonoids. They are found in citrus fruits such as oranges and lemons (Manach et al., 2005).

Finally, Anthocyanidins lack the keto group at $\mathrm{C} 4$ and present a hydroxyl group at C3 and the double bond between C3-C4 of ring C; because of these structural characteristics, they are the only cationic flavonoids and present swift changes in colour depending on the $\mathrm{pH}$ of the fruit. Almost all anthocyanidins are glycosylated (De La Rosa et al., 2018).

\subsection{Non-flavonoids}

The second group of PCs is known as non-flavonoids, which present simpler structures when compared to flavonoids. They include phenolic acids, stilbenes, lignans and other polyphenols (Libro et al., 2016).

Phenolic acids are divided into two main groups: hydroxybenzoic acids (C6-C1) and hydroxycinnamic acids (C6-C3) (Garrido \& Borges, 2013). These types of PCs can be found in free form in fruits and vegetables, or as conjugates in seeds and grains (Murkovic, 2015).

The main hydroxybenzoic acids (C6-C1 skeleton) are gallic, gentisic, p-hydroxybenzoic, syringic, salicylic, and vanillic acid (Rentzsch et al., 2009). These compounds are mainly present in fruits and vegetables such as berries, nuts, tea, spices, or wine. They are usually found as glycosidic derivatives or bound to organic acids or IDF (Manach et al., 2005; Rentzsch et al., 2009). These acids have also been found as complex polymeric forms bound to carbohydrates, known as hydrolysable tannins (De La Rosa et al., 2018).
The main hydroxycinnamic acids (C6-C3 backbone) are p-coumaric, caffeic, and methylated forms of ferulic and sinapic acids. Chlorogenic acid is the main caffeic acid derivative is (Garrido \& Borges, 2013; Rentzsch et al., 2009). They are found in cereals, coffee, tomatoes, and grapes, or in processed foods such as beer and wine. (Garrido \& Borges, 2013; Manach et al., 2005).

Stilbenes are formed by two aromatic rings joined by an ethene bridge (C6-C2-C6). They are found in plants as cis or trans-isomers. Resveratrol is the main stilbene, is found mainly in grapes and wine (Álvarez Parrilla et al., 2012).

Lignans are compounds made by two phenylpropanoid units (C6-C3-C3-C6). There are 200 types of lignans distributed in the plant kingdom (MacRae \& Towers, 1984). They can be found in whole grain cereals, beans, berries, and particularly in red wine, tea, and coffee (Adlercreutz, 2007).

\section{Antioxidant dietary fiber}

Saura-Calixto defined antioxidant dietary fiber (ADF) as "a product containing significant amounts of natural antioxidants associated with the fiber matrix". The author enlisted three requirements in order to consider a DF as ADF: 1) DF content (AOAC method 43.A14 - 43.A20) should be higher than $50 \%$ on a dry basis, 2) one $\mathrm{g}$ of ADF should have the capacity to inhibit lipid oxidation equivalent to, at least, $200 \mathrm{mg}$ of vitamin $\mathrm{E}$, and 3) the antioxidant capacity must be an intrinsic property, derived from natural constituents of the material, it should neither be the result of added antioxidants nor of constituents released by previous chemical or enzymatic treatments (Saura-Calixto, 1998). Hydroxycinnamic acids, both monomeric and polymeric (hydrolysable tannins), are the main PCs associated with DF. The formation of $\mathrm{ADF}$ comprises both covalent and non-covalent interactions between PCs and DF (Figure 3).

The main covalent interactions between PCs and DF are through glycosidic linkages and ester bonds between DF and hydroxyl groups of PCs (González Aguilar et al., 2017; Jakobek, 2015). Non-covalent interactions include hydrogenic bonds, van der Waals forces, and hydrophobic interactions, between hydroxyl and aromatic rings of PC and DF. (Jakobek, 2015; Simonsen et al., 2009).

It must be considered that $\mathrm{FD}$ and PCs have beneficial effects on their own; however, these properties may be compromised when interacting with each other (Saura-Calixto, 1998). For these reasons, the participation of any other molecule that may interfere with the DF-PC complex should be assessed to avoid undesired health effects (Rein et al., 2013). Assessing such interference may be of particular interest when formulating new functional foods using by-products rich in DF and PC.

\section{Use of agro-industrial by-products in bakery products}

Bakery goods are some of the most consumed products in several cultures around the world (Arranz-Otaegui et al., 2018; Mesas \& Alegre, 2002). However, their high content of carbohydrates (starch and sugars) and fats can be a contributing factor to overweight or obesity among consumers (Serra-Majem 


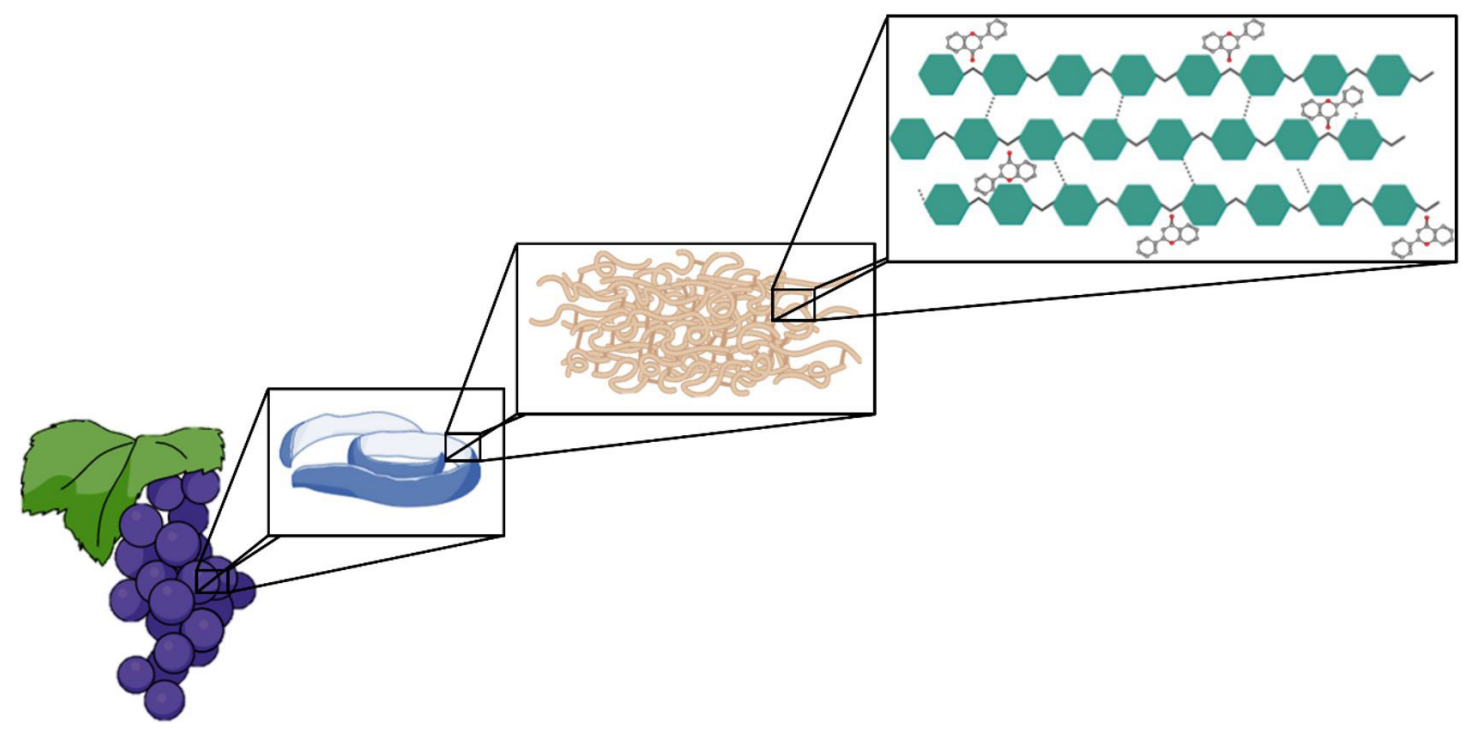

Figure 3. Interaction between PCs and DF in a food matrix.

\& Bautista-Castaño, 2015). For this reason, the use of functional ingredients from agro-industrial by-products in the formulation of bakery products has gained relevance among researchers and the food industry.

Although by-products are agro-industrial waste, they can be considered a potential source of BCs with applications as functional ingredients (Helkar et al., 2016). The industrial activities that generate the most by-products are cereal, dairy products, brewery, marine products, meat, fruit and vegetables. However, depending on the nature of the by-product, it can be used as a source of beneficial compounds for human consumption (Ayala-Zavala et al., 2011). For example, some by-products have been used as antibrowning additives due to their high content of organic acids (ascorbic, malic, and phosphoric acid) and phenolic compounds; as antimicrobial mainly due to their essential oils and phenolic compounds, or as a source of specific BCs such as DF, PCs or specific minerals (Ayala-Zavala et al., 2011; Olivas-Aguirre et al., 2017).

Some bakery products have been enriched with by-products, such as is the case of cakes enriched with DF and protein content using potato peel powder (Ben Jeddou et al., 2017) and apple pomace (Sudha et al., 2007); dough biscuits with DF enriched with PCs and carotenoids using mango peel powder (Ajila et al., 2008); gluten-free cookies with DF using plantain peel flour (García-Solís et al., 2018); cookies and bread with DF using unripe mango fruit (Vergara-Valencia et al., 2007); bread with DF using jack fruit rind powder (Felli et al., 2018); and bread, muffins and brownies with DF and enriched with PCs using wine grape pomace (Walker et al., 2014) among others (Table 1).

One of the main reasons to incorporate by-products into bread formulations is to increase their BC content. Studies have focused mainly on the addition of by-products to increase the content of PCs and DF. Table 2 summarizes the effect of the addition of by-products on PCs, DF (soluble and insoluble) content, and antioxidant capacity of bakery products added with by-products. Even though by-products have been extensively studied to determine their BCs composition, mainly PCs, DF and minerals, few studies have evaluated the interaction of PCs and DF (ADF) in bakery products enriched with by-products.

When pecan nut pellets from pecan oil extraction were added to a muffin, the cohesiveness and resilience increased while the hardness and adhesiveness decreased (Marchetti et al., 2018). On the other hand, the muffin added with grape pomace had a better texture and flavour, while the colour, appearance and acceptance properties were negatively affected (MildnerSzkudlarz et al., 2015). In the case of the doughnut added with red potato peel, the hardness, adhesiveness, cohesiveness, and elasticity increased (Rivera-Dommarco et al., 2013). The presence of mango peel powder and apple pomace in biscuits reduced the attributes of colour, texture, flavour, and firmness. Additionally, mango powder also affected the sweetness and sourness of the bread product (Ajila et al., 2008; Alongi et al., 2019). The addition of coffee by-product to a biscuit, increased its flexibility and hardness (Passos et al., 2017). Unlike the rest of the biscuit formulations, the addition of pumpkin seed powder increased the overall appearance, colour, aroma, flavour, and texture of the biscuit, and it was better accepted (Malkanthi et al., 2018). In this same sense, a cookie enriched with grape pomace also increased the aroma, appearance and acceptability while keeping the rest of the attributes the same but increasing the BCs (Maner et al., 2017). Similar results were observed for a rice cracker fortified with apple pomace (Mir et al., 2017). Studies have reported that the addition of by-products to bread modifies the textural properties mainly by the increasing PCs and DF, which may interact with the dough preventing the formation of gluten ramification (Mildner-Szkudlarz et al., 2015; Smith \& Yu, 2015).

One of the main reasons to incorporate by-products into bakery formulations is to increase their BC content. Studies 


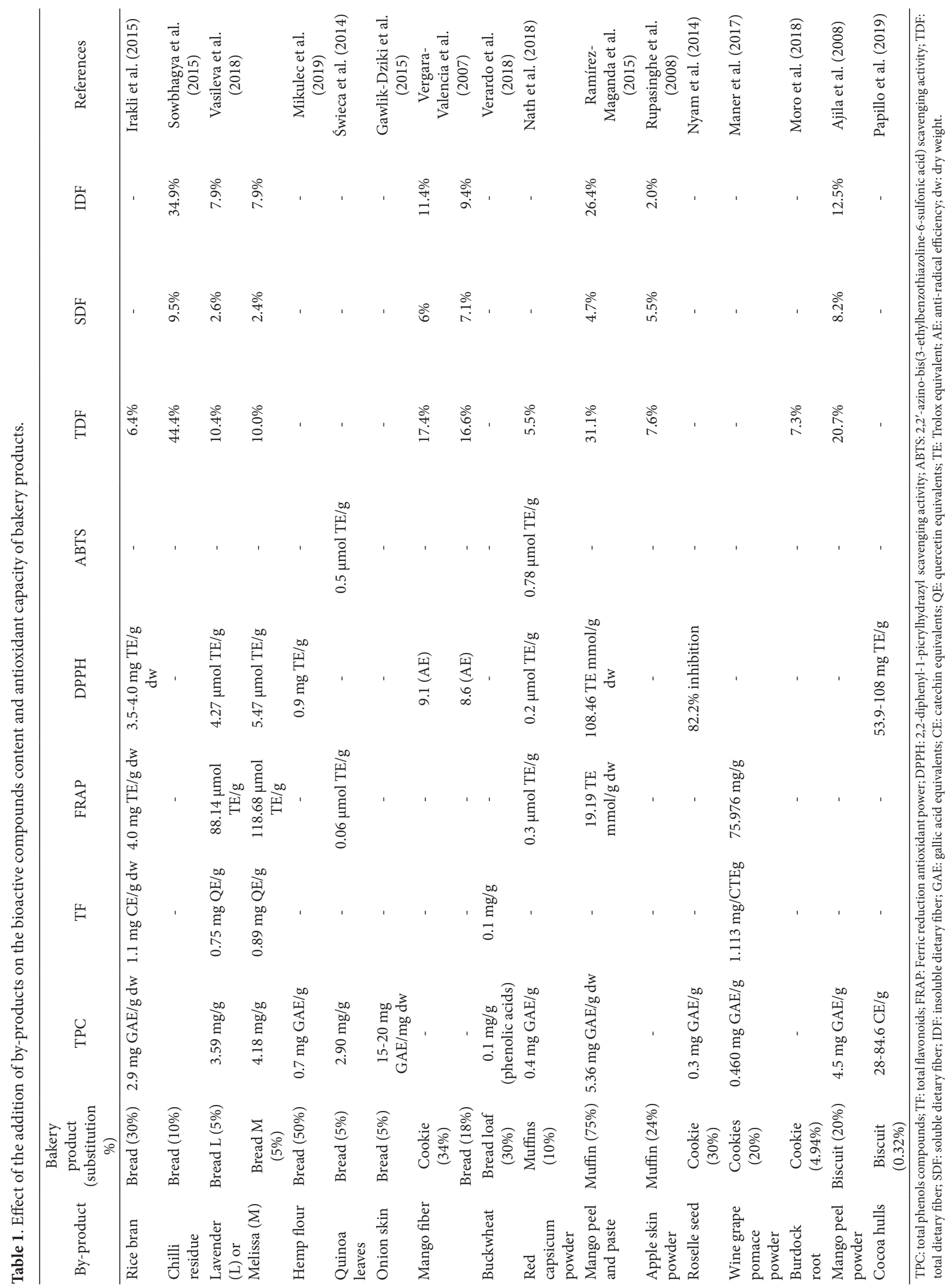




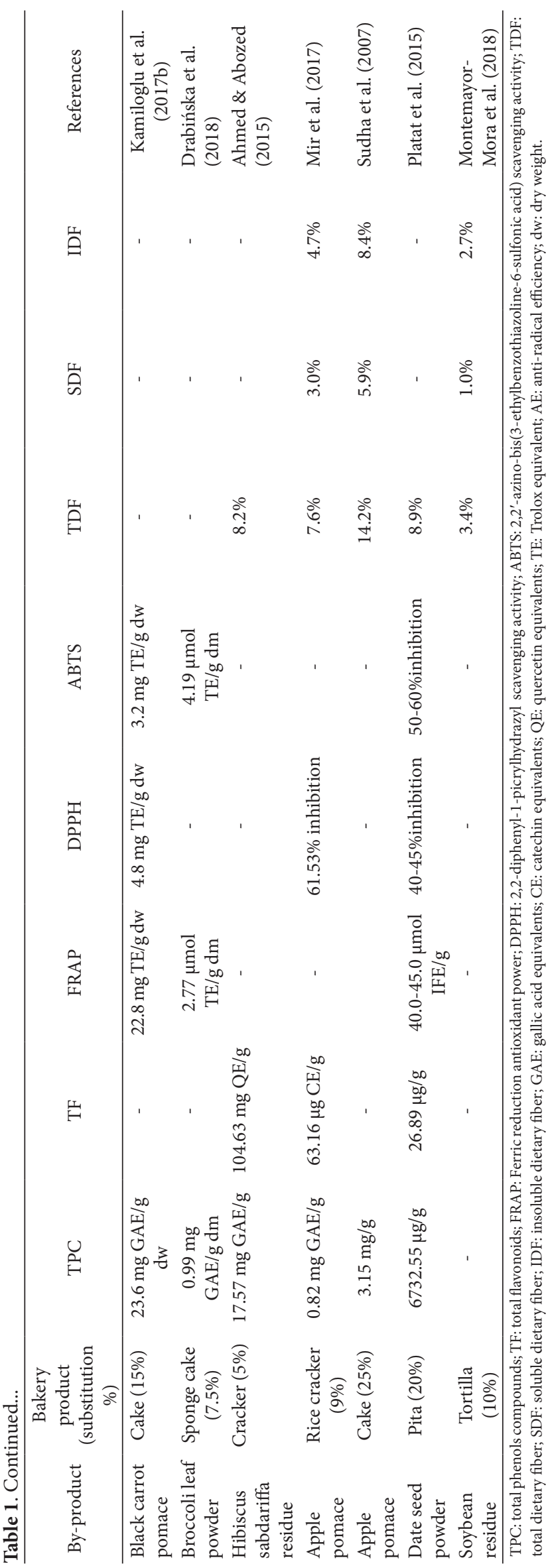




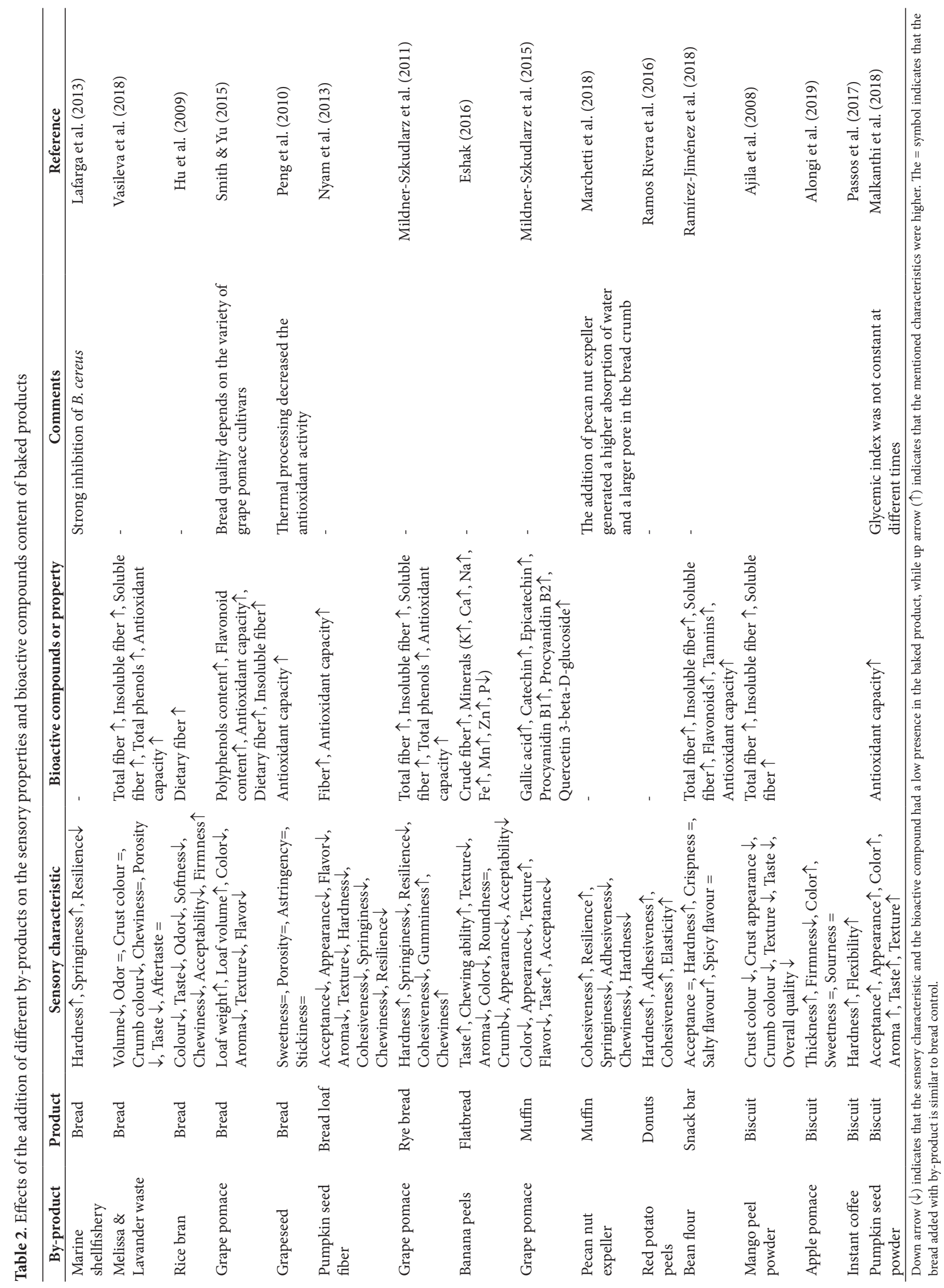


Subiria-Cueto et al.

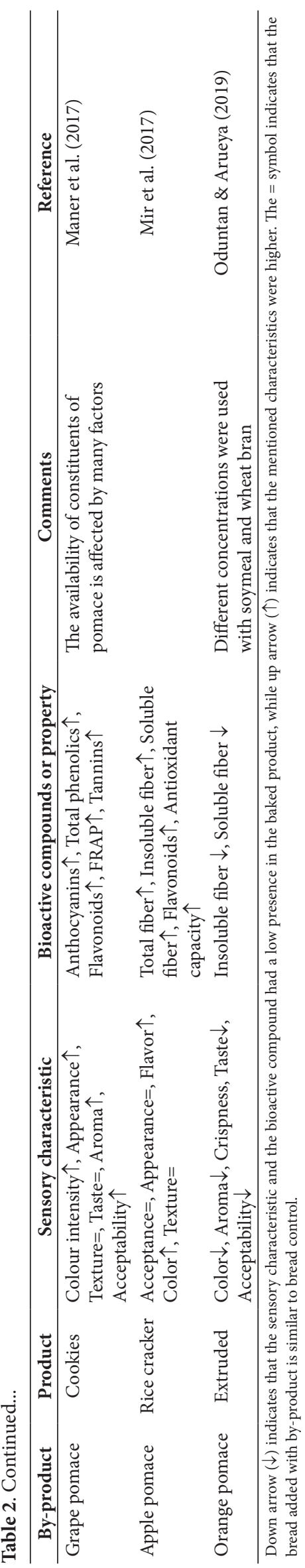


have focused mainly on the addition of by-products to increase the content of PC and DF. Table 2 summarizes the effect of the addition of by-products to the PC, DF (soluble and insoluble) content and antioxidant capacity of bakery products enriched with by-products. Although the composition of BCs in byproducts have been extensively studied in order to determine their BCs composition, mainly PCs, DF and minerals, few studies had evaluated the interaction of PCs and DF (ADF) in bakery products enriched with by-products. In this sense, it is necessary to consider which factors of bread making (fermentation, bakery, storage) directly affect $\mathrm{BC}$ contents and interactions. Also, it is essential to compare the BCs of the enriched product against one that has not been enriched to determine significant differences between DF and PCs (Ajila et al., 2008; Irakli et al., 2015; Mir et al., 2017; Platat et al., 2015; Ramírez-Maganda et al., 2015; Sudha et al., 2007; Vasileva et al., 2018).

The percentage of substitution of wheat flour in bakery products with by-product flour depends on their characteristics. Substitutions as high as $75 \%$ have been observed for mango peel and paste (Ramírez-Maganda et al., 2015). While in rice bran, hemp flour, red capsicum powder mango fiber, roselle seed, buckwheat, apple skin powder, wine grape pomace and black carrot pomace have shown substitutions between 10-35\% (Ajila et al., 2008; Irakli et al., 2015; Maner et al., 2017; Nath et al., 2018; Nyam et al., 2014; Nyambe-Silavwe et al., 2015; RamírezMaganda et al., 2015; Rupasinghe et al., 2008; Verardo et al., 2018; Vergara-Valencia et al., 2007). In contrast, other by-products such as lavender, melissa, quinoa leaves, burdock root and hibiscus sabdariffa barely reached 5\% substitution (Ahmed \& Abozed, 2015; Moro et al., 2018; Świeca et al., 2014; Vasileva et al., 2018). Among the products that have been enriched with by-products stand out bread, cookies, muffins, cakes, pita, rice crackers and tortillas. All these examples demonstrate the versatility of adding by-products in the formulation of bakery products (Kamiloglu et al., 2017a; Mir et al., 2017; Montemayor-Mora et al., 2018; Platat et al., 2015). Tables 1 and 2 show that bread is the most widely used product when it comes to incorporating different by-products, considering that bread formulation can be easily modified to retain the original content of the main macronutrients.

According to different studies, adding by-products to bakery products increased PCs (0.03 to $2.36 \%$ ) and DF (3.4 to $44.4 \%)$ (Kamiloglu et al., 2017a; Montemayor-Mora et al., 2018; Nyam et al., 2014; Sowbhagya et al., 2015). However, this enrichment could affect positively or negatively the characteristics of the food. For instance, the addition of marine shellfish by-products into bread increased the hardness, springiness, and resilience (Lafarga et al., 2013); the addition of rice increased the firmness, while decreased the softness, chewiness and overall acceptability of a formulated bread (Hu et al., 2009). Also, the addition of grape pomace to bread increased weight and volume of the loaf, while decreasing its sensory texture perception (Smith \& Yu, 2015). When grape pomace was added to rye bread, the hardness, chewiness and gumminess increased, whereas the springiness, cohesiveness and resilience decreased (Mildner-Szkudlarz et al., 2011). The addition of pumpkin seed fiber modified all textural properties of bread loaf (Nyam et al., 2013). When pecan nut pellet (from pecan oil extraction) was added to a muffin, the cohesiveness and resilience increased while the hardness and adhesiveness decreased (Marchetti et al., 2018). On the other hand, the muffin added with grape pomace had a better texture and flavour; however, the colour, appearance, and acceptance properties were negatively affected (Mildner-Szkudlarz et al., 2015). In the case of the doughnuts enriched with red potato peel, the hardness, adhesiveness, cohesiveness, and elasticity increased (Rivera-Dommarco et al., 2013). Powdered mango peel and apple pomace added to biscuits reduced the attributes of colour, texture, flavour, and firmness, on the other hand, sweetness and sourness were not affected when only apple pomace was added (Ajila et al., 2008; Alongi et al., 2019). The addition of coffee by-product to a biscuit increased flexibility and hardness (Passos et al., 2017). Unlike the rest of the biscuits formulations, the addition of pumpkin seed powder increased the overall appearance, colour, aroma, flavour, texture and was better accepted (Malkanthi et al., 2018). In this same sense, a cookie with grape pomace also increased the aroma, appearance and acceptability keeping the rest of the attributes the same and increasing the BCs (Maner et al., 2017). Similar results were observed for a rice cracker enriched with apple pomace (Mir et al., 2017).

Studies have reported that adding by-products to bread modify its textural properties, increasing PCs and DF which, in turn, may interact with the dough preventing the formation of gluten ramification (Mildner-Szkudlarz et al., 2015; Smith \& Yu, 2015). In contrast, better notes can be perceived in the food when by-products are added. Such bitter notes may be caused by PCs such as tannins or bread porosity size, which can be affected by DF (IDF and SDF) content (Frewer et al., 2011; Marco et al., 2017). When undesirable alterations in the new product appear, its formulation must be adjusted or modified to minimize this undesirable effect (González Aguilar et al., 2017; Gorinstein et al., 2011). When undesirable alterations in the developed a product appear, the formulation must be adjusted to minimize any undesirable effect (González Aguilar et al., 2017; Gorinstein et al., 2011)

The acceptance of a product plays an essential role in its consumption. Some by-product enriched foods have been evaluated regarding consumer preferences, using hedonic scales and obtaining good acceptability. In the case of grape pomaceadded cookies, good acceptability was observed for pomace flour (5\% substitution) and pomace flour without seed (5\% substitution) cookies (Acun \& Gül, 2014). A pancake (30\%), a cereal bar (5\%), and a cookie (5\%) substituted with grape pomace reported overall acceptance (3.9, 4.0 and 4.3) similar to those of the controls (5.7, 3.9 and 3.6) (Maner et al., 2017; Rosales Soto et al., 2012). A vital characteristic of the products is that the cereal bar and the pancake had double, and triple antioxidant capacity compared to the controls (Rosales Soto et al., 2012). Furthermore, a cookie enriched with grape pomace had twice the antioxidant activity (FRAP), total phenols, and twelve times more anthocyanins (Maner et al., 2017). In the case of DF, more studies are needed to prove the relationship between acceptability and soluble or insoluble fiber content.

Even though the PC profile determined by HPLC-MS has been extensively studied in by-products, the number of studies that evaluate the PC profile in by-product fortified bakery products is small, and results are summarized in Table 3. Almost all studies used methanol/water extractions for the isolation 


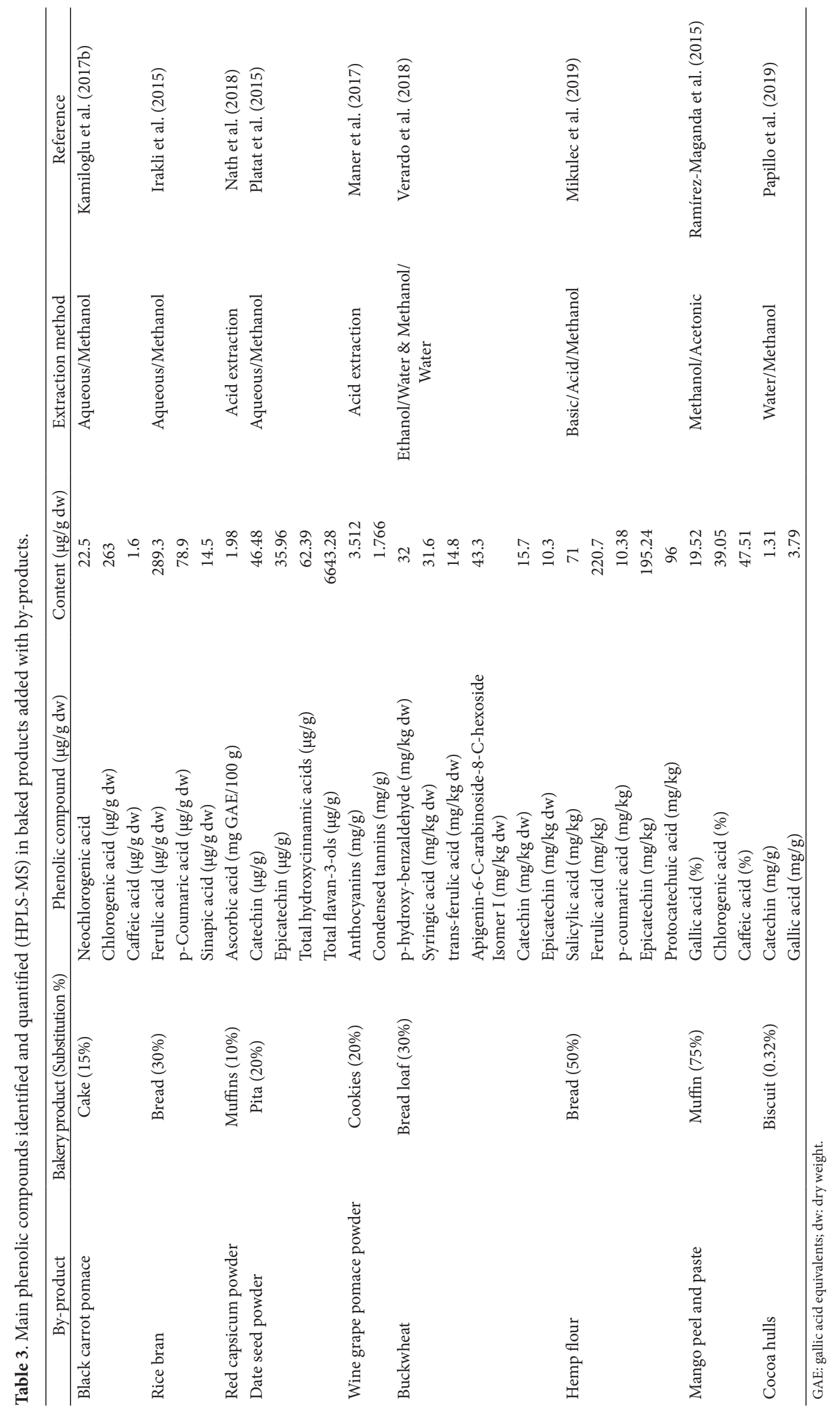


Table 4. Biological effects of baked products added with by-products.

\begin{tabular}{|c|c|c|c|c|}
\hline By-product & $\begin{array}{l}\text { Bakery product } \\
\text { (Substitution \%) }\end{array}$ & In vitro studies & Human studies & References \\
\hline Pumpkin seed powder & Biscuits & - & Glycemic index & $\begin{array}{l}\text { Serra-Majem \& Bautista- } \\
\quad \text { Castaño (2015) }\end{array}$ \\
\hline Mango peel \& paste & Muffin & Digestive enzyme inhibition ( $\alpha$-amylase) & - & Nyam et al. (2013) \\
\hline Black carrot pomace & Cake & Phenolic compounds release in digestive system & - & Tassoni et al. (2020) \\
\hline Rice bran & Bread & $\begin{array}{l}\text { Bioaccessibility in gastric and gastrointestinal } \\
\text { digestion }\end{array}$ & - & Vasileva et al. (2018) \\
\hline Apple pomace & Biscuits & Glycemic index by digestive system & - & Saura-Calixto (1998) \\
\hline Mango fiber & Cookie \& bread & Glycemic index by digestive system & - & Mesas \& Alegre (2002) \\
\hline
\end{tabular}

of PC. Phenolic acids were the main PC identified in a cake fortified with black carrot pomace, among them ferulic and chlorogenic acid (Kamiloglu et al., 2017b). In hemp flour fortified bread ferulic acid and epicatechin were the mainly quantified PCs (Mikulec et al., 2019). Catechin has also been reported in products fortified with red capsicum powder, buckwheat, and cocoa hulls (Nath et al., 2018; Papillo et al., 2019; Verardo et al., 2018). Anthocyanins and condensed tannins have been quantified in wine grape pomace fortified cookies (Maner et al., 2017).

\section{Health benefits of enriching bakery products}

By-product fortification of bakery goods is designed to increase PC and DF content, keeping in mind the high caloric index of bakery products. Such an increase in PC and DF are related to a decrease in the glycemic index. However, the number of studies that evaluated the health-related effects of these products is scarce and is summarized in Table 4. Most of the studies were in vitro assays that evaluated the inhibition of digestive enzymes, bioaccessibility of PC, and glycemic index.

The objective of inhibiting digestive enzymes (amylase, lipase, and trypsin) is to prevent the absorption of macromolecules (lipids and carbohydrates). It has been observed that PCs have the capacity to inactivate these enzymes and generate a health benefit (Martinez-Gonzalez et al., 2019; Podsędek et al., 2014). The addition of mango peel and paste into a muffin formulation showed to inhibit $\alpha$-amylase, probably cause of the increase of PCs in the sample (Ramírez-Maganda et al., 2015). On the other hand, bioaccessibility experiments seek to quantify the PCs released from a food matrix during in vitro digestion. With this type of studies, it is possible to evaluate the amount of PC that are released at each digestive stage, allowing them to have a physiological impact. They also quantify how strongly PCs bound to the food matrix (González Aguilar et al., 2017; MercadoMercado et al., 2015). In the case of bread enriched with rice bran, it was observed that the bioaccessibility of PCs is directly affected by the presence of DF. The release of phytochemicals is diminished by the interaction with the fiber components (Irakli et al., 2019). In the same way, black carrot pomace was used to make different formulations of cakes. Monitoring changes in antioxidant capacity during different digestive stages of these products revealed an increase in the release of PCs in each in vitro digestion step (Kamiloglu et al., 2017b).

The in vitro glycemic index evaluates the release of glucose at different in vitro gastric stages (Domínguez-Avila et al., 2017).
These in vitro glycemic indexes were evaluated with two fortified bakery products enriched with apple pomace and mango fiber. In both cases, the glycemic indices were lower compared those of the controls (Alongi et al., 2019; Vergara-Valencia et al., 2007). Authors attributed this lower glycemic index values to the action of DF. There is only one study in which the effect of a pumpkin seed powder fortified biscuit on the glycemic index was evaluated. In this study, the authors observed blood glucose decrease at $\min 30(107.86 \mathrm{mg} / \mathrm{dl})$, compared to control biscuits $(115.71 \mathrm{mg} / \mathrm{dl})$. Such decrease was the result of the content of crude fiber of pumpkin seed powder (Malkanthi et al., 2018).

\section{Conclusion}

Alternative food sources, such as by-products, are a rich source of PCs and DF. In addition, BCs can be used for the development and improvement of bakery products to improve overall health. BCs interactions should also be observed and analyzed to assess both PC and DF may have in ameliorating different diseases. However, for each new formulation, studies regarding the bioaccessibility of phytochemicals, as well as acceptability studies, should definitively be carried out.

\section{References}

Acun, S., \& Gül, H. (2014). Effects of grape pomace and grape seed flours on cookie quality. Quality Assurance and Safety of Crops \& Foods, 6(1), 81-88. http://dx.doi.org/10.3920/QAS2013.0264.

Adlercreutz, H. (2007). Lignans and human health. Critical Reviews in Clinical Laboratory Sciences, 44(5-6), 483-525. http://dx.doi. org/10.1080/10408360701612942. PMid:17943494.

Ahmad, A., \& Khalid, N. (2018). Dietary fibers in modern food production: a special perspective with $\beta$-glucans. In A. M. Grumezescu \& A. M. Holban (Eds.), Biopolymers for food design (pp. 125-156). London: Elsevier. http://dx.doi.org/10.1016/B978-0-12-811449-0.00005-0.

Ahmed, Z. S., \& Abozed, S. S. (2015). Functional and antioxidant properties of novel snack crackers incorporated with Hibiscus sabdariffa by-product. Journal of Advanced Research, 6(1), 79-87. http://dx.doi.org/10.1016/j.jare.2014.07.002. PMid:25685546.

Ajila, C. M., Leelavathi, K., \& Prasada Rao, U. J. S. (2008). Improvement of dietary fiber content and antioxidant properties in soft dough biscuits with the incorporation of mango peel powder. Journal of Cereal Science, 48(2), 319-326. http://dx.doi.org/10.1016/j.jcs.2007.10.001.

Alongi, M., Melchior, S., \& Anese, M. (2019). Reducing the glycemic index of short dough biscuits by using apple pomace as a functional ingredient. Lebensmittel-Wissenschaft + Technologie, 100, 300-305. http://dx.doi.org/10.1016/j.lwt.2018.10.068. 
Álvarez Parrilla, E., González Aguilar, G. A., De la Rosa, L. A, \& Ayala Zavala, F. (2012). Antioxidantes en alimentos y salud. México: Universidad Autónoma de Ciudad Juárez.

Arranz-Otaegui, A., Gonzalez Carretero, L., Ramsey, M. N., Fuller, D. Q., \& Richter, T. (2018). Archaeobotanical evidence reveals the origins of bread 14, 400 years ago in northeastern Jordan. Proceedings of the National Academy of Sciences of the United States of America, 115(31), 7925-7930. http://dx.doi.org/10.1073/pnas.1801071115. PMid:30012614.

Ayala-Zavala, J. F., Vega-Vega, V., Rosas-Domínguez, C., Palafox-Carlos, H., Villa-Rodriguez, J. A., Siddiqui, M. W., Dávila-Aviña, J. E., \& González-Aguilar, G. A. (2011). Agro-industrial potential of exotic fruit byproducts as a source of food additives. Food Research International, 44(7), 1866-1874. http://dx.doi.org/10.1016/j.foodres.2011.02.021.

Badui Dergal, S. (2012). Química de los alimentos (5th ed.). México: Pearson Educación.

Ben Jeddou, K., Bouaziz, F., Zouari-Ellouzi, S., Chaari, F., Ellouz-Chaabouni, S., Ellouz-Ghorbel, R., \& Nouri-Ellouz, O. (2017). Improvement of texture and sensory properties of cakes by addition of potato peel powder with high level of dietary fiber and protein. Food Chemistry, 217, 668-677. http://dx.doi.org/10.1016/j.foodchem.2016.08.081. PMid:27664685.

Burton, P., \& Lightowler, H. J. (2006). Influence of bread volume on glycaemic response and satiety. British Journal of Nutrition, 96(5), 877-882. http://dx.doi.org/10.1017/BJN20061900. PMid:17092376.

Caprita, A., Caprita, R., Ginet Simulescu, V. O., \& Raluca-Madalina, D. (2010). Dietary fiber: chemical and functional properties. Journal of Agroalimentary Processes and Technologies, 16(4), 406-416.

Day, L., Seymour, R. B., Pitts, K. F., Konczak, I., \& Lundin, L. (2009). Incorporation of functional ingredients into foods. Trends in Food Science \& Technology, 20(9), 388-395. http://dx.doi.org/10.1016/j. tifs.2008.05.002.

De La Rosa, L. A., Moreno-Escamilla, J. O., Rodrigo-García, J., \& Alvarez-Parrilla, E. (2018). Phenolic compounds. In E. M. Yahia \& A. Carrillo-Lopez (Eds.), Postharvest physiology and biochemistry of fruits and vegetables. Duxford: Woodhead Publishing.

Dhingra, D., Michael, M., Rajput, H., \& Patil, R. T. (2012). Dietary fibre in foods: a review. Journal of Food Science and Technology, 49(3), 255266. http://dx.doi.org/10.1007/s13197-011-0365-5. PMid:23729846.

Domínguez-Avila, J. A., Wall-Medrano, A., Velderrain-Rodríguez, G. R., Chen, C. Y. O., Salazar-López, N. J., Robles-Sánchez, M., \& González-Aguilar, G. A. (2017). Gastrointestinal interactions, absorption, splanchnic metabolism and pharmacokinetics of orally ingested phenolic compounds. Food \& Function, 8(1), 15-38. http:// dx.doi.org/10.1039/C6FO01475E. PMid:28074953.

Drabińska, N., Ciska, E., Szmatowicz, B., \& Krupa-Kozak, U. (2018). Broccoli by-products improve the nutraceutical potential of glutenfree mini sponge cakes. Food Chemistry, 267, 170-177. http://dx.doi. org/10.1016/j.foodchem.2017.08.119. PMid:29934153.

Drago Serrano, M., López López, M., \& Saínz Espuñes, T. (2006). Componentes bioactivos de alimentos funcionales de origen vegetal. Revista Mexicana de Ciencias Farmacéuticas, 37(4), 58-68.

Dziki, D., Rózyło, R., Gawlik-Dziki, U., \& Świeca, M. (2014). Current trends in the enhancement of antioxidant activity of wheat bread by the addition of plant materials rich in phenolic compounds. Trends in Food Science \& Technology, 40(1), 48-61. http://dx.doi. org/10.1016/j.tifs.2014.07.010.

Escudero Álvarez, E., \& Gonzalez Sánchez, P. (2006). La fibra dietética. Nutrición Hospitalaria, 21(Suppl. 2), 61-72.
Eshak, N. S. (2016). Sensory evaluation and nutritional value of balady flat bread supplemented with banana peels as a natural source of dietary fiber. Annals of Agricultural Science, 61(2), 229-235. http:// dx.doi.org/10.1016/j.aoas.2016.07.002.

Felli, R., Yang, T. A., Wan Abdullah, W. N., \& Zzaman, W. (2018). Effects of incorporation of jackfruit rind powder on chemical and functional properties of bread. Tropical Life Sciences Research, 29(1), 113-126. http://dx.doi.org/10.21315/tlsr2018.29.1.8. PMid:29644019.

Flecha, M. (2015). Procesos y técnicas de panificación. México.

Frewer, L. J., Bergmann, K., Brennan, M., Lion, R., Meertens, R., Rowe, G., Siegrist, M., \& Vereijken, C. (2011). Consumer response to novel agri-food technologies: implications for predicting consumer acceptance of emerging food technologies. Trends in Food Science \& Technology, 22(8), 442-456. http://dx.doi.org/10.1016/j.tifs.2011.05.005.

Garcia, E. F., Luciano, W. A., Xavier, D. E., Costa, W. C. A., Oliveira, K. D. S., Franco, O. L., Morais, M. A., Jr., Lucena, B. T. L., Picão, R. C., Magnani, M., Saarela, M., \& de Souza, E. L. (2016). Identification of lactic acid bacteria in fruit pulp processing byproducts and potential probiotic properties of selected Lactobacillus strains. Frontiers in Microbiology, 7, 1371. http://dx.doi.org/10.3389/fmicb.2016.01371. PMid:27625647.

García-Solís, S. E., Bello-Pérez, L. A., Agama-acevedo, E., \& Flores-silva, P. C. (2018). Plantain flour: A potential nutraceutical ingredient to increase fiber and reduce starch digestibility of gluten-free cookies. Stärke, 70(1-2), 1-5. http://dx.doi.org/10.1002/star.201700107.

Garrido, J., \& Borges, F. (2013). Wine and grape polyphenols: a chemical perspective. Food Research International, 54(2), 1844-1858. http:// dx.doi.org/10.1016/j.foodres.2013.08.002.

Gawlik-Dziki, U., Kaszuba, K., Piwowarczyk, K., Świeca, M., Dziki, D., \& Czyż, J. (2015). Onion skin: raw material for the production of supplement that enhances the health-bene fi cial properties of wheat bread. Food Research International, 73, 97-106. http://dx.doi. org/10.1016/j.foodres.2015.02.008.

González Aguilar, G., Blancas Bénitez, F., \& Sáyago-Ayerdi, S. (2017). Polyphenols associated with dietary fibers in plant foods: molecular interactions and bioaccessibility. Current Opinion in Food Science, 13, 84-88. http://dx.doi.org/10.1016/j.cofs.2017.03.004.

Gorinstein, S., Poovarodom, S., Leontowicz, H., Leontowicz, M., Namiesnik, J., Vearasilp, S., Haruenkit, R., Ruamsuke, P., Katrich, E., \& Tashma, Z. (2011). Antioxidant properties and bioactive constituents of some rare exotic Thai fruits and comparison with conventional fruits: in vitro and in vivo studies. Food Research International, 44(7), 2222-2232. http://dx.doi.org/10.1016/j.foodres.2010.10.009.

Halake, K., Birajdar, M., \& Lee, J. (2016). Structural implications of polyphenolic antioxidants. Journal of Industrial and Engineering Chemistry, 35, 1-7. http://dx.doi.org/10.1016/j.jiec.2016.01.003.

Helkar, P. B., Sahoo, A. K., \& Patil, N. J. (2016). Review: food industry by-products used as a functional food ingredients. International Journal of Waste Resources, 6(3), 1-6.

Herrera, A. (2013). Importancia de la fibra en la alimentación y recomendaciones nutricionales del consumo. Revista Gatrohnup, 15(2), S19-S25.

Hu, G., Huang, S., Cao, S., \& Ma, Z. (2009). Effect of enrichment with hemicellulose from rice bran on chemical and functional properties of bread. Food Chemistry, 115(3), 839-842. http://dx.doi.org/10.1016/j. foodchem.2008.12.092.

Irakli, M., Katsantonis, D., \& Kleisiaris, F. (2015). Evaluation of quality attributes, nutraceutical components and antioxidant potential of wheat bread substituted with rice bran. Journal of Cereal Science, 65, 74-80. http://dx.doi.org/10.1016/j.jcs.2015.06.010. 
Irakli, M., Mygdalia, A., Chatzopoulou, P., \& Katsantonis, D. (2019). Impact of the combination of sourdough fermentation and hop extract addition on baking properties, antioxidant capacity and phenolics bioaccessibility of rice bran-enhanced bread. Food Chemistry, 285, 231-239. http://dx.doi.org/10.1016/j.foodchem.2019.01.145. PMid:30797340.

Jakobek, L. (2015). Interactions of polyphenols with carbohydrates, lipids and proteins. Food Chemistry, 175, 556-567. http://dx.doi. org/10.1016/j.foodchem.2014.12.013. PMid:25577120.

Kamiloglu, S., Ozkan, G., Isik, H., Horoz, O., Van Camp, J., \& Capanoglu, E. (2017a). Black carrot pomace as a source of polyphenols for enhancing the nutritional value of cake: An in vitro digestion study with a standardized static model. Lebensmittel-Wissenschaft + Technologie, 77, 475-481. http://dx.doi.org/10.1016/j.lwt.2016.12.002.

Kamiloglu, S., Ozkan, G., Isik, H., Horoz, O., Van Camp, J., \& Capanoglu, E. (2017b). Black carrot pomace as a source of polyphenols for enhancing the nutritional value of cake: an in vitro digestion study with a standardized static model. Lebensmittel-Wissenschaft + Technologie, 77, 475-481. http://dx.doi.org/10.1016/j.lwt.2016.12.002.

Kay, R. M. (1982). Dietary fiber. Journal of Lipid Research, 23(2), 221-242. http://dx.doi.org/10.1016/S0022-2275(20)38151-7. PMid:6281350.

Lafarga, T., Gallagher, E., Walsh, D., Valverde, J., \& Hayes, M. (2013). Chitosan-containing bread made using marine shellfishery byproducts: functional, bioactive, and quality assessment of the end product. Journal of Agricultural and Food Chemistry, 61(37), 8790-8796. http://dx.doi.org/10.1021/jf402248a. PMid:23962198.

Libro, R., Giacoppo, S., Soundara Rajan, T., Bramanti, P., \& Mazzon, E. (2016). Natural phytochemicals in the treatment and prevention of dementia: an overview. Molecules, 21(4), 518. http://dx.doi. org/10.3390/molecules21040518. PMid:27110749.

MacRae, W. D., \& Towers, G. H. N. (1984). Biological activities of lignans. Phytochemistry, 23(6), 1207-1220. http://dx.doi.org/10.1016/ S0031-9422(00)80428-8.

Malkanthi, H., Umadevi, S., \& Jamuna, K. (2018). Glycemic response and antioxidant activity of pumpkin seed powder (Cucurbita maxima) blended biscuits. Journal of Pharmacognosy and Phytochemistry, 7(4), 1877-1882.

Manach, C., Williamson, G., Morand, C., Scalbert, A., \& Rémésy, C. (2005). Bioavailability and bioefficacy of polyphenols in humans. I. Review of 97 bioavailability studies. The American Journal of Clinical Nutrition, 81(1, Suppl.), 230-242. http://dx.doi.org/10.1093/ ajcn/81.1.230S. PMid:15640486.

Maner, S., Sharma, A. K., \& Banerjee, K. (2017). Wheat flour replacement by wine grape pomace powder positively affects physical, functional and sensory properties of cookies. Proceedings of the National Academy of Sciences. India. Section B, Biological Sciences, 87(1), 109-113. http://dx.doi.org/10.1007/s40011-015-0570-5.

Marchetti, L., Califano, A. N., \& Andrés, S. C. (2018). Partial replacement of wheat flour by pecan nut expeller meal on bakery products: effect on muffins quality. Lebensmittel-Wissenschaft + Technologie, 95, 85-91. http://dx.doi.org/10.1016/j.lwt.2018.04.050.

Marco, M. L., Heeney, D., Binda, S., Cifelli, C. J., Cotter, P. D., Foligné, B., Gänzle, M., Kort, R., Pasin, G., Pihlanto, A., Smid, E. J., \& Hutkins, R. (2017). Health benefits of fermented foods: microbiota and beyond. Current Opinion in Biotechnology, 44, 94-102. http:// dx.doi.org/10.1016/j.copbio.2016.11.010. PMid:27998788.

Martinez-Gonzalez, A. I., Díaz-Sánchez, G., de la Rosa, L. A., BustosJaimes, I., \& Alvarez-Parrilla, E. (2019). Inhibition of $\alpha$-amylase by flavonoids: structure activity relationship (SAR). Spectrochimica Acta. Part A: Molecular and Biomolecular Spectroscopy, 206, 437447. http://dx.doi.org/10.1016/j.saa.2018.08.057. PMid:30172871.
Martinez-Saez, N., García, A. T., Pérez, I. D., Rebollo-Hernanz, M., Mesías, M., Morales, F. J., Martín-Cabrejas, M. A., \& Del Castillo, M. D. (2017). Use of spent coffee grounds as food ingredient in bakery products. Food Chemistry, 216, 114-122. http://dx.doi.org/10.1016/j. foodchem.2016.07.173. PMid:27596399.

Mercado-Mercado, G., Blancas-Benitez, F. J., Velderrain-Rodríguez, G. R., Montalvo-González, E., González-Aguilar, G. A., Alvarez-Parrilla, E., \& Sáyago-Ayerdi, S. G. (2015). Bioaccessibility of polyphenols released and associated to dietary fibre in calyces and decoction residues of Roselle (Hibiscus sabdariffa L.). Journal of Functional Foods, 18, 171-181. http://dx.doi.org/10.1016/j.jff.2015.07.001.

Mesas, J. M., \& Alegre, M. T. (2002). El pan y su proceso de elaboración. Food Science and Technology, 3(5), 307-313. https://doi.org/1135-8122.

Mikulec, A., Kowalski, S., Sabat, R., Skoczylas, Ł., Tabaszewska, M., \& Wywrocka-Gurgul, A. (2019). Hemp flour as a valuable component for enriching physicochemical and antioxidant properties of wheat bread. Lebensmittel-Wissenschaft + Technologie, 102, 164-172. http:// dx.doi.org/10.1016/j.lwt.2018.12.028.

Mildner-Szkudlarz, S., Siger, A., Szwengiel, A., \& Bajerska, J. (2015). Natural compounds from grape by-products enhance nutritive value and reduce formation of CML in model muffins. Food Chemistry, 172, 78-85. http://dx.doi.org/10.1016/j.foodchem.2014.09.036. PMid:25442526.

Mildner-Szkudlarz, S., Zawirska-Wojtasiak, R., Szwengiel, A., \& Pacyński, M. (2011). Use of grape by-product as a source of dietary fibre and phenolic compounds in sourdough mixed rye bread. International Journal of Food Science \& Technology, 46(7), 1485-1493. http:// dx.doi.org/10.1111/j.1365-2621.2011.02643.x.

Mir, S. A., Bosco, S. J. D., Shah, M. A., Santhalakshmy, S., \& Mir, M. M. (2017). Effect of apple pomace on quality characteristics of brown rice based cracker. Journal of the Saudi Society of Agricultural Sciences, 16(1), 25-32. http://dx.doi.org/10.1016/j.jssas.2015.01.001.

Montemayor-Mora, G., Hernández-Reyes, K. E., Heredia-Olea, E., Pérez-Carrillo, E., Chew-Guevara, A. A., \& Serna-Saldívar, S. O. (2018). Rheology, acceptability and texture of wheat flour tortillas supplemented with soybean residue. Journal of Food Science and Technology, 55(12), 4964-4972. http://dx.doi.org/10.1007/s13197018-3432-3. PMid:30482992.

Moro, T. M. A., Celegatti, C. M., Pereira, A. P. A., Lopes, A. S., Barbin, D. F., Pastore, G. M., \& Clerici, M. T. P. S. (2018). Use of burdock root flour as a prebiotic ingredient in cookies. Lebensmittel-Wissenschaft + Technologie, 90, 540-546. http://dx.doi.org/10.1016/j.lwt.2017.12.059.

Mudgil, D., \& Barak, S. (2013). Composition, properties and health benefits of indigestible carbohydrate polymers as dietary fiber: a review. International Journal of Biological Macromolecules, 61, 1-6. http://dx.doi.org/10.1016/j.ijbiomac.2013.06.044. PMid:23831534.

Murkovic, M. (2015). Phenolic compounds: occurrence, classes, and analysis. In B. Caballero, P. Finglas \& F. Toldra (Eds.), Encyclopedia of food sciences and nutrition (pp. 2827-2832). London: Academic Press. https://doi.org/10.1016/B978-0-12-384947-2.00539-0.

Nath, P., Kale, S. J., Kaur, C., \& Chauhan, O. (2018). Phytonutrient composition, antioxidant activity and acceptability of muffins incorporated with red capsicum pomace powder. Journal of Food Science and Technology, 55(6), 2208-2219. http://dx.doi.org/10.1007/ s13197-018-3138-6. PMid:29892122.

Nyam, K. L., Lau, M., \& Tan, C. P. (2013). Fibre from pumpkin (Cucurbita pepo L.) seeds and rinds: physico-chemical properties, antioxidant capacity and application as bakery product ingredients. Malaysian Journal of Nutrition, 19(1), 99-110. PMid:24800388.

Nyam, K. L., Leao, S. Y., Tan, C. P., \& Long, K. (2014). Functional properties of roselle (Hibiscus sabdariffa L.) seed and its application as bakery 
product. Journal of Food Science and Technology, 51(12), 3830-3837. http://dx.doi.org/10.1007/s13197-012-0902-x. PMid:25477650.

Nyambe-Silavwe, H., Villa-Rodriguez, J. A., Ifie, I., Holmes, M., Aydin, E., Jensen, J. M., \& Williamson, G. (2015). Inhibition of human a-amylase by dietary polyphenols. Journal of Functional Foods, 19, 723-732. http://dx.doi.org/10.1016/j.jff.2015.10.003.

Oduntan, A. O., \& Arueya, G. L. (2019). Design, formulation, and characterization of a potencial "whole food" using fibre rich orange (Citrus sinensis Lin) pomace as base. Bioactive Carbohydrates and Dietary Fibre, 17, 1-8. http://dx.doi.org/10.1016/j.bcdf.2018.10.001.

Olivas-Aguirre, F. J., Gaytán-Martínez, M., Mendoza-Díaz, S. O., González-Aguilar, G. A., Rodrigo-García, J., Martínez-Ruiz, N. del R., \& Wall-Medrano, A. (2017). In vitro digestibility of phenolic compounds from edible fruits: could it be explained by chemometrics? International Journal of Food Science \& Technology, 52(9), 2040-2048. http://dx.doi.org/10.1111/ijfs.13482.

Panche, A. N., Diwan, A. D., \& Chandra, S. R. (2016). Flavonoids: an overview. Journal of Nutritional Science, 5, e47. http://dx.doi. org/10.1017/jns.2016.41. PMid:28620474.

Papillo, V. A., Locatelli, M., Travaglia, F., Bordiga, M., Garino, C., Coïsson, J. D., \& Arlorio, M. (2019). Cocoa hulls polyphenols stabilized by microencapsulation as functional ingredient for bakery applications. Food Research International, 115, 511-518. http://dx.doi.org/10.1016/j. foodres.2018.10.004. PMid:30599972.

Passos, C. P., Kukurová, K., Basil, E., Fernandes, P. A. R., Neto, A., Nunes, F. M., Murkovic, M., Ciesarová, Z., \& Coimbra, M. A. (2017). Instant coffee as a source of antioxidant-rich and sugar-free coloured compounds for use in bakery: application in biscuits. Food Chemistry, 231, 114-121. http://dx.doi.org/10.1016/j.foodchem.2017.03.105. PMid:28449987.

Peng, X., Ma, J., Cheng, K. W., Jiang, Y., Chen, F., \& Wang, M. (2010). The effects of grape seed extract fortification on the antioxidant activity and quality attributes of bread. Food Chemistry, 119(1), 49-53. http://dx.doi.org/10.1016/j.foodchem.2009.05.083.

Platat, C., Habib, H. M., Hashim, I. B., Kamal, H., AlMaqbali, F., Souka, U., \& Ibrahim, W. H. (2015). Production of functional pita bread using date seed powder. Journal of Food Science and Technology, 52(10), 6375-6384. http://dx.doi.org/10.1007/s13197-015-1728-0. PMid:26396382.

Podsẹdek, A., Majewska, I., Redzynia, M., Sosnowska, D., \& Koziołkiewicz, M. (2014). In vitro inhibitory effect on digestive enzymes and antioxidant potential of commonly consumed fruits. Journal of Agricultural and Food Chemistry, 62(20), 4610-4617. http://dx.doi. org/10.1021/jf5008264. PMid:24785184.

Ramírez-Jiménez, A. K., Gaytán-Martínez, M., Morales-Sánchez, E., \& Loarca-Piña, G. (2018). Functional properties and sensory value of snack bars added with common bean flour as a source of bioactive compounds. Lebensmittel-Wissenschaft + Technologie, 89(141), 674-680. http://dx.doi.org/10.1016/j.lwt.2017.11.043.

Ramírez-Maganda, J., Blancas-Benítez, F. J., Zamora-Gasga, V. M., García-Magaña, M. de L., Bello-Pérez, L. A., Tovar, J., \& SáyagoAyerdi, S. G. (2015). Nutritional properties and phenolic content of a bakery product substituted with a mango (Mangifera indica) "Ataulfo" processing by-product. Food Research International, 73, 117-123. http://dx.doi.org/10.1016/j.foodres.2015.03.004.

Ramos Rivera, E. M., Moreno Velázquez, A. L., Romero Muñoz, I. G., Piloni Martini, P., Hernández Uribe, J. P., Quintero Lira, A., Soto Simental, S., \& Güemes Vera, N. (2016). Analisis de perfil de textura en masas y donas de harina de trigo con harinas de cáscara de Oxalis tuberosa. Investigación y Desarrollo en Ciencia y Tecnología de Alimentos, 1(1), 26-30. Retrieved from http://www.fcb.uanl.mx/ IDCyTA/files/volume1/1/1/5.pdf

Rein, M. J., Renouf, M., Cruz-Hernandez, C., Actis-Goretta, L., Thakkar, S. K., \& da Silva Pinto, M. (2013). Bioavailability of bioactive food compounds: a challenging journey to bioefficacy. British Journal of Clinical Pharmacology, 75(3), 588-602. http://dx.doi.org/10.1111/ j.1365-2125.2012.04425.x. PMid:22897361.

Rentzsch, M., Wilkens, A., \& Winterhalter, P. (2009). Non-flavonoid Phenolic Compounds Michael. In M. V. Moreno-Arribas \& M. C. Polo (Eds.), Wine chemistry and biochemistry (pp. 509-527). New York: Springer. https://doi.org/10.1007/978-0-387-74118-5.

Rincón-León, F. (2003). Functional foods. In B. Caballero, P. Finglas \& F. Toldra (Eds.), Encyclopedia of food sciences and nutrition (pp. 2827-2832). London: Academic Press. https://doi.org/10.1016/B012-227055-X/01328-6.

Rivera-Dommarco, J. Á., Cuevas-Nasu, L., De Cosío, T. G., ShamahLevy, T., \& García-Feregrino, R. (2013). Desnutrición crónica en México en el último cuarto de siglo: análisis de cuatro encuestas nacionalse. Salud Pública de México, 55(Suppl. 2), 161-169. http:// dx.doi.org/10.21149/spm.v55s2.5112.

Rosales Soto, M. U., Brown, K., \& Ross, C. F. (2012). Antioxidant activity and consumer acceptance of grape seed flour-containing food products. International Journal of Food Science \& Technology, 47(3), 592-602. http://dx.doi.org/10.1111/j.1365-2621.2011.02882.x.

Rupasinghe, H. P. V., Wang, L., Huber, G. M., \& Pitts, N. L. (2008). Effect of baking on dietary fibre and phenolics of muffins incorporated with apple skin powder. Food Chemistry, 107, 1217-1224.

Sagar, N. A., Pareek, S., Sharma, S., Yahia, E. M., \& Lobo, M. G. (2018). Fruit and vegetable waste: bioactive compounds, their extraction, and possible utilization. Comprehensive Reviews in Food Science and Food Safety, 17(3), 512. http://dx.doi.org/10.1111/1541-4337.12330. PMid:33350136.

Saura-Calixto, F. (1998). Antioxidant dietary fiber product: a new concept and a potential. Journal of Agricultural and Food Chemistry, 46(10), 4303-4306. http://dx.doi.org/10.1021/jf9803841.

Segneanu, A., Velciov, S. M., Olariu, S., Cziple, F., Damian, D., \& Grozescu, I. (2017). Bioactive molecules profile from natural compounds. In T. Asao \& M. Asaduzzaman (Eds.), Amino acid: new insights and roles in plant and animal. London: IntechOpen. http://dx.doi. org/10.5772/intechopen.68643.

Serra-Majem, L., \& Bautista-Castaño, I. (2015). Relationship between bread and obesity. British Journal of Nutrition, 113(Suppl. 2), S29-S35. http://dx.doi.org/10.1017/S0007114514003249. PMid:26148919.

Silveira Rodríguez, M. B., Monereo Megías, S., \& Molina Baena, B. (2003). Alimentos funcionales y nutrición óptima: ¿cerca o lejos? Revista Espanola de Salud Publica, 77(3), 317-331. http://dx.doi. org/10.1590/S1135-57272003000300003. PMid:12852326.

Simonsen, H. T., Nielsen, M. S., Christensen, N. J., Christensen, U., La Cour, T. V., Motawia, M. S., Jespersen, B. P. M., Engelsen, S. B., \& Møller, B. L. (2009). Molecular interactions between Barley and Oat $\beta$-glucans and phenolic derivatives. Journal of Agricultural and Food Chemistry, 57(5), 2056-2064. http://dx.doi.org/10.1021/ jf802057v. PMid:19256561.

Siró, I., Kápolna, E., Kápolna, B., \& Lugasi, A. (2008). Functional food: product development, marketing and consumer acceptance: a review. Appetite, 51(3), 456-467. http://dx.doi.org/10.1016/j. appet.2008.05.060. PMid:18582508.

Smith, I. N., \& Yu, J. (2015). Nutritional and sensory quality of bread containing different quantities of grape pomace from different grape cultivars. EC Nutrition, 2, 291-301. 
Sowbhagya, H. B., Soumya, C., Indrani, D., \& Srinivas, P. (2015). Physico-chemical characteristics of chilli spent residue and its effect on the rheological, microstructural and nutritional qualities of bread. Journal of Food Science and Technology, 52(11), 7218-7226. http:// dx.doi.org/10.1007/s13197-015-1824-1.

Sudha, M. L., Baskaran, V., \& Leelavathi, K. (2007). Apple pomace as a source of dietary fiber and polyphenols and its effect on the rheological characteristics and cake making. Food Chemistry, 104(2), 686-692. http://dx.doi.org/10.1016/j.foodchem.2006.12.016.

Świeca, M., Sẹczyk, Ł., Gawlik-Dziki, U., \& Dziki, D. (2014). Bread enriched with quinoa leaves: the influence of protein-phenolics interactions on the nutritional and antioxidant quality. Food Chemistry, 162, 54-62. http://dx.doi.org/10.1016/j.foodchem.2014.04.044. PMid:24874357.

Tassoni, A., Tedeschi, T., Zurlini, C., Cigognini, I. M., Petrusan, J. I., Rodríguez, Ó., Neri, S., Celli, A., Sisti, L., Cinelli, P., Signori, F., Tsatsos, G., Bondi, M., Verstringe, S., Bruggerman, G., \& Corvini, P. F. X. (2020). State-of-the-art production chains for peas, beans and chickpeas: valorization of agro-industrial residues and applications of derived extracts. Molecules, 25(6), 1383. http://dx.doi.org/10.3390/ molecules25061383. PMid:32197427.

Tebben, L., Shen, Y., \& Li, Y. (2018). Improvers and functional ingredients in whole wheat bread: a review of their effects on dough properties and bread quality. Trends in Food Science \& Technology, 81, 10-24. http://dx.doi.org/10.1016/j.tifs.2018.08.015.
Tomás-Barberán, F. A., \& Clifford, M. N. (2000). Dietary hydroxybenzoic acid derivatives: nature, occurrence and dietary burden. Journal of the Science of Food and Agriculture, 80(7), 1024-1032. http:// dx.doi.org/10.1002/(SICI)1097-0010(20000515)80:7<1024::AIDJSFA567>3.0.CO;2-S.

Vasileva, I., Denkova, R., Chochkov, R., Teneva, D., Denkova, Z., Dessev, T., Denev, P., \& Slavov, A. (2018). Effect of lavender (Lavandula angustifolia) and melissa (Melissa Officinalis) waste on quality and shelf life of bread. Food Chemistry, 253, 13-21. http://dx.doi. org/10.1016/j.foodchem.2018.01.131. PMid:29502812.

Verardo, V., Glicerina, V., Cocci, E., Frenich, A. G., Romani, S., \& Caboni, M. F. (2018). Determination of free and bound phenolic compounds and their antioxidant activity in buckwheat bread loaf, crust and crumb. Lebensmittel-Wissenschaft + Technologie, 87, 217 224. http://dx.doi.org/10.1016/j.lwt.2017.08.063.

Vergara-Valencia, N., Granados-Pérez, E., Agama-Acevedo, E., Tovar, J., Ruales, J., \& Bello-Pérez, L. A. (2007). Fibre concentrate from mango fruit: characterization, associated antioxidant capacity and application as a bakery product ingredient. Lebensmittel-Wissenschaft + Technologie, 40(4), 722-729. http://dx.doi.org/10.1016/j.lwt.2006.02.028.

Walker, R., Tseng, A., Cavender, G., Ross, A., \& Zhao, Y. (2014). Physicochemical, nutritional, and sensory qualities of wine grape pomace fortified baked goods. Journal of Food Science, 79(9), S1811-S1822. http://dx.doi.org/10.1111/1750-3841.12554. PMid:25102950. 